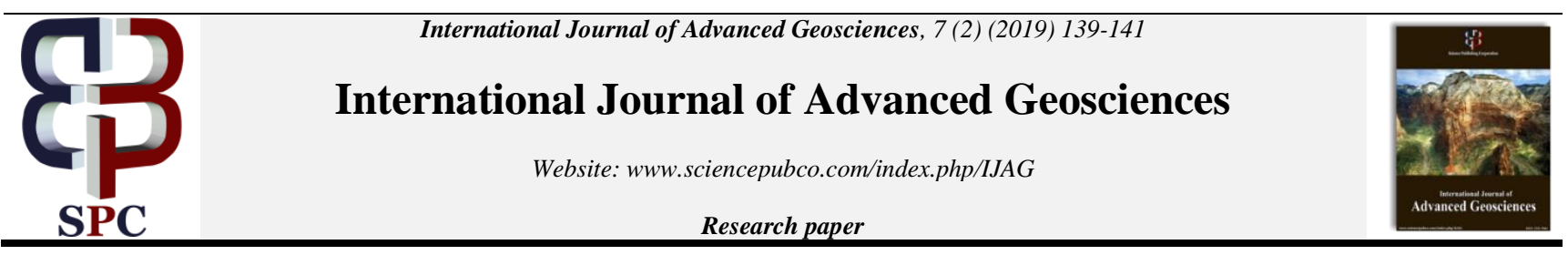

\title{
Long-term fertilization effect of organic carbon and total nitrogen on floodplain soil
}

\author{
Md. Majharul Islam ${ }^{1}$ *, Md. Forhad Hossain ${ }^{1}$, Md. Mukul Mia ${ }^{2}$, Md. Shaidul Islam ${ }^{3}$, \\ Md. Saikat Hossain Bhuiyan ${ }^{1}$, Joynul Alam Talukder ${ }^{5}$, M. Abdul Kader ${ }^{4}$ \\ ${ }^{1}$ Soil Science Division, Bangladesh Institute of Nuclear Agriculture. Mymenshingh, Bangladesh \\ ${ }^{2}$ Breeding Division, Bangladesh Jute Research Institute, Dhaka, Bangladesh \\ ${ }^{3}$ Bangladesh Agricultural Research Council, Dhaka, Bangladesh \\ ${ }^{4}$ Bangladesh Agricultural University, Mymensinghh, Bangladesh \\ ${ }^{5}$ Department of Agricultural Extension, Kishorganj, Bangladesh \\ *Corresponding author E-mail: m.islambau03@gmail.com
}

\begin{abstract}
Soil organic matter is the most often reported indicator of soil quality and productivity and an evidence of previous soil management. Therefore, in 2017, a laboratory incubation study was carried out in the experimental filed of Bangladesh Institute of Nuclear Agriculture (BINA), Mymensingh, Bangladesh under control condition at $25^{\circ} \mathrm{C}$ for 104 days to investigate the influence of long term manuring and fertilization on soil respiration by means of $\mathrm{C}$ mineralization. Soil samples were collected from floodplain soil with rice-rice cropping pattern at Bangladesh Agricultural University (BAU) experimental farm having eight treatments. Long term (33 years) application of fertilizers and manure resulted in significant differences in soil organic carbon, total $\mathrm{N}$ content, and soil $\mathrm{pH} \mathrm{KCl}$ between the treatments. The soil organic carbon and total $\mathrm{N}$ content varied among the different treatments from $14.9 \mathrm{~g} \mathrm{OC} \mathrm{kg-1} \mathrm{to} 17.0 \mathrm{~g} \mathrm{OC} \mathrm{kg-1} \mathrm{and1.60} \mathrm{g} \mathrm{N}$ kg-1 (control) to $1.78 \mathrm{~g} \mathrm{~N} \mathrm{kg-1} \mathrm{(application} \mathrm{of} \mathrm{NPK).} \mathrm{The} \mathrm{soil} \mathrm{pH}$ varied among the different treatments from 5.65(application of NK) to 4.89 (application of N). This result indicates that more stable organic carbon was formed in NPK treated soil which is less prone to decomposition if present crop management has been changed.
\end{abstract}

Keywords: C: N Ratio; Long Term Fertilization; Organic Carbon; Total N.

\section{Introduction}

Soil organic carbon (SOC) is of importance for maintaining soil fertility and to sustaining the productivity. SOC is also the source and sink of atmospheric $\mathrm{CO}_{2}$ and plays a key role in global $\mathrm{C}$ cycling. For an example, globally soils contain 1500 Pg of soil organic carbon (SOC). Therefore, keeping a satisfactory level of SOC is significant for ensuring food security and mitigating climate warming. Soil carbon mineralization and the $\mathrm{CO}_{2}$ evolution has been paid great attention for its important effect on the global carbon cycle and terrestrial ecosystem functioning (IPCC, 2001; Valentini et al., 2000; Jenkinson et al., 1991). Any changes in mineralization rate could significantly impact the size of the atmospheric $\mathrm{CO}_{2}$-carbon (C) pool that has been estimated as $800 \mathrm{Pg}$.

Organic manuring and inorganic fertilizer application are the most common agricultural practices. Many studies reported that inorganic fertilizer application resulted in significant increases in SOC and its fractions due to the positive effects of the fertilizer on crop growth and in turn crop C return (Gong et. al., 2009). However, in other studies, inorganic fertilizer application, either balanced or unbalanced, showed no significant effects on SOC or its fractions. These inconsistent results may be related to the additional rate and balance status of fertilizer, crop residue management, tillage regime and experimental duration (Su et. al., 2006). Organic manuring, either alone or in combination with inorganic fertilizer, has been widely shown more effective in increasing SOC and its factions than inorganic fertilizer alone mainly due to the significant increase in $\mathrm{C}$ input with the manure application.

Fertilization had a significantly beneficial impact on soil microbial properties, and, in particular, continuous compost fertilization improved markedly soil microbial properties compared with chemical fertilization only. The importance of fertilization and manuring of our land is increasing day by day and farmers are supposed to use these inputs intensively for sustained crop production. Practices of intensive fertilization and manuring undoubtedly bring some changes in the physical and chemical properties of soil as well as biological properties.

\section{Materials and methods}

The long term experimental soil used in this study was established in 1978 at the Department of Soil Science, Bangladesh Agricultural University (BAU), Mymensingh ( $\left.24^{\circ} 43^{\prime} \mathrm{N}, 90^{\circ} 25^{\prime} \mathrm{E}\right)$, and Bangladesh on loamy, mixed, nonacid Aeric Haplaquepts (Soil Taxonomy) developed from old Brahmaputra alluvium. Soil samples were collected from long-term field experiments in May-July 2017. The soil 
texture was silt loam (19, 63 and 18\% sand, silt and clay, respectively). The treatments all have a yearly boro rice-fallow-aman rice cropping pattern and included an unfertilized control, six treatments with application of mineral fertilizer (control, N, NP, NS, NK, NPK, $50 \% \mathrm{~N}+\mathrm{FYM}$ and NPKSZn) and one treatment with application of mineral $\mathrm{N}$ and farmyard manure (50\% $+\mathrm{FYM})$. The application rates of $\mathrm{N}, \mathrm{P}, \mathrm{K}, \mathrm{S}$, and $\mathrm{Zn}$ per crop were 90, 20, 19, 30, and $5 \mathrm{~kg} \mathrm{ha}^{-1}$, respectively applied as urea, triple superphosphate, muriate of potash, gypsum, and zinc oxide, respectively. Cowdung mixed with rice straw was applied as farmyard manure at a rate of $5 \mathrm{Mg} \mathrm{ha}^{-1}$ fresh material and once a year. Chemical fertilizers were applied to every crop and were incorporated to soil during final land preparation preceding rice transplantation, except for $\mathrm{N}$ which was applied as basal-dressing and two times as top-dressing in three equal doses. The experiment was conducted in a randomized block design with three replicate plots $(12 \mathrm{mx} 6 \mathrm{~m})$. The cropping pattern was rice-fallow-rice as high yielding Boro rice and high yielding T. Aman rice.

Surface soil samples $(0-15 \mathrm{~cm})$ were collected from 15 locations per replicate plot by means of an auger $(2.5 \mathrm{~cm})$. These samples were bulked into one composite sample and were thoroughly mixed. The field moist soil was gently broken apart by hand and was air-dried and ground to pass a 2-mm sieve prior to soil incubations, determination of soil properties and other studies.

The total carbon and nitrogen content of soil samples were analysed with a Variomax CNS-analyzer (Elementar Analysesysteme, Germany). Sub-samples of $0.8 \mathrm{~g}$ were used for analysis. The CNS analyzer works according to the principle of catalytic tube combustion under excess oxygen supply and high temperatures $\left(850^{\circ} \mathrm{C}\right.$ to $\left.1150^{\circ} \mathrm{C}\right)$. The $\mathrm{pH}(\mathrm{KCl})$ was determined for all soils with a $\mathrm{pH}$-electrode. Means separation analysis was used to calculate parameters from cumulative C mineralization data in SPSS. One-way ANOVA with Duncan's multiple range post-hoc tests was used for statistical analysis. Correlation study was also performed between soil parameters, C mineralization parameters, enzyme activities and previously collected crop yields. All statistical analyses were carried out with SPSS 17.

\section{Results}

\subsection{Organic carbon}

Long term (33 years) application of mineral fertilizers and manure to floodplain soil resulted in significant differences $(\mathrm{P}<0.01)$ in soil organic carbon content between the treatments (Table 1). The highest SOC content was observed in NPK plot and the lowest in NS treated plot. Different fertilizer and manure application resulted in a significantly accumulation of SOC compared to the control. This is in line with some previous studies (Huang et al., 2010) who reported that continuous fertilizer application increased the concentrations of SOC, TN and other nutrients in plough layers compared with the initial value at the beginning of the experiment. In the present study, it is observed that, soil organic carbon increases with the increase of $\mathrm{N}$-fertilizer application. However, in few experiments soil organic $\mathrm{C}$ did not increase until $\mathrm{N}$ was applied at rates in excess of that required for maximum yield. For an example, Yadav (1998) found an increase in organic $\mathrm{C}$, available $\mathrm{N}$ and total $\mathrm{N}$ content in two locations out of four in 16 years long-term fertilizer experiment under rice wheat cropping pattern.

\subsection{Total $\mathbf{N}$}

Similar to observations for SOC, long term (33 years) application of mineral fertilizers and manure to the BAU floodplain soil resulted in significant differences $(\mathrm{P}<0.01)$ in soil nitrogen content between the treatments (Table 1). This study shows that total $\mathrm{N}$ low in control and high in NPK. That total N content was significantly greater in the fertilized field than in the non-fertilized field. Total N content in the NP, NK, NPK, N+FYM and NPKSZn treated plots was not significantly different. Consequently, long term application of P, K or FYM in combination with $\mathrm{N}$ had a significant influence on soil $\mathrm{N}$ content. Addition of fertilizer and manure resulted in a significantly higher $\mathrm{N}$ content compared to the control. This is in line with Ramulu (1990) who observed that total N content of soil was higher in NP, NPK and cattle manure plots compared to other treatments. Total $\mathrm{N}$ content of soil was significantly increased with the increase of $\mathrm{N}$-fertilizer application. This could be due to the fact that part of the applied $\mathrm{N}$ fertilizer immobilized particularly manure amended plots due to wider $\mathrm{C}: \mathrm{N}$ ratios of exogenous organic matter. Most of this immobilized $\mathrm{N}$ remain in the soil profile and contribute to the buildup of soil total $\mathrm{N}$.

\subsection{C: $\mathrm{N}$ ratio}

The C: $\mathrm{N}$ ratios of the soil varied among the different treatments from 9.0 (NP) to 9.5 (NPK). Narrow range in C: $\mathrm{N}$ ratios of the soils indicating proportional increase in $\mathrm{C}$ and $\mathrm{N}$ in the fertilizer treatments. Addition of fertilizer manure resulted in a decline in soil $\mathrm{C}$ : $\mathrm{N}$ ratios compared to the control but the differences were insignificant (Table 1). Molkonen (1991) stated that nitrogen fertilization decreased $\mathrm{C}: \mathrm{N}$ ratio of the humus layer.

Table 1: Influence of Long Term Application of Mineral Fertilizers and FYM on Soil Properties

\begin{tabular}{lllll}
\hline Treatments & Organic carbon $\left(\mathrm{g} \mathrm{kg}^{-1}\right)$ & Total N $\left(\mathrm{g} \mathrm{kg}^{-1}\right)$ & $\mathrm{C}: \mathrm{N} \mathrm{ratio}(-)$ & $\mathrm{pH}_{\mathrm{KCl}}(-)$ \\
\hline $\mathrm{N}$ & $15.3 \mathrm{bcd}$ & $1.64 \mathrm{bc}$ & 9.3 & $5.85 \mathrm{a}$ \\
$\mathrm{NP}$ & $15.8 \mathrm{abcd}$ & $1.75 \mathrm{ab}$ & 9.0 & $5.67 \mathrm{c}$ \\
$\mathrm{NS}$ & $14.9 \mathrm{~d}$ & $1.64 \mathrm{bc}$ & 9.1 & $5.67 \mathrm{c}$ \\
$\mathrm{NK}$ & $16.5 \mathrm{abc}$ & $1.76 \mathrm{ab}$ & 9.4 & $5.65 \mathrm{c}$ \\
$\mathrm{NPK}$ & $17.0 \mathrm{a}$ & $1.78 \mathrm{a}$ & 9.5 & $5.70 \mathrm{bc}$ \\
$\mathrm{N}+\mathrm{FYM}$ & $16.6 \mathrm{ab}$ & 9.4 & $5.74 \mathrm{bc}$ \\
$\mathrm{NPKSZn}$ & $16.0 \mathrm{abcd}$ & $1.77 \mathrm{a}$ & $5.79 \mathrm{ab}$ \\
ANOVA & $* *$ & $1.73 \mathrm{ab}$ & 9.3 & $* *$ \\
\hline
\end{tabular}

*** Significant at $\mathrm{P} \leq 0.01 \& \mathrm{P} \leq 0.05$, respectively. NS, not significant. Treatment indicated by different letters are statistically different $(\mathrm{P}<0.05)$ from each other according to Duncan's multiple range post hoc test.

\subsection{Soil pH}

Long term (33 years) application of mineral fertilizers and manure to floodplain soil resulted in significant differences $(\mathrm{P}<0.01)$ in soil $\mathrm{pH}$ between the treatments (Table 3.1). The soil pH varied among the different treatments from 5.65(application of NK) to 4.89 (application of $\mathrm{N}$ ). The highest soil $\mathrm{pH}$ was observed with the application of $\mathrm{N}$ followed by other treatments. The soil $\mathrm{pH}$ was decreased to a certain extent with different fertilizer treatments. In this study pH is high in N+FYM than NPK. Suwara and Kulesza (1990) reported that FYM 
had stronger effect on $\mathrm{pH}$ than of NPK fertilizer. However, this finding is in contrast with many others (Bajpai et. al., 1980) who observed that repeated application of manure or FYM to the soil reduced the soil pH. It is hypothesized that application of organic matter to the soil decreases the $\mathrm{pH}$ due to production of organic acids during decomposition of organic matter.

\section{Discussion}

Application of mineral fertilizers and manure to the BAU floodplain soil resulted in significant differences in soil organic carbon, total $\mathrm{N}$ content, soil $\mathrm{pH}$ and insignificant differences in $\mathrm{C}: \mathrm{N}$ ratio of soil between the treatments. The soil organic carbon content varied among the different treatments from $14.9 \mathrm{~g} \mathrm{OC} \mathrm{kg}^{-1}$ to $17.0 \mathrm{~g} \mathrm{OC} \mathrm{kg}^{-1}$. Organic carbon content was only significantly different between NS and NPK application treatments. The highest SOC content was observed in NPK plot and the lowest in NS treated plot. Different fertilizer and manure application resulted in a significantly accumulation of SOC compared to the control. The total soil $\mathrm{N}$ content varied among the different treatments from $1.60 \mathrm{~g} \mathrm{~N} \mathrm{~kg}^{-1}$ (control) to $1.78 \mathrm{~g} \mathrm{~N} \mathrm{~kg}^{-1}$ (application of NPK). Consequently, long term application of P, K or FYM in combination with $\mathrm{N}$ had a significant influence on soil $\mathrm{N}$ content. Addition of fertilizer and manure resulted in a significantly higher $\mathrm{N}$ content compared to the control. $\mathrm{C}: \mathrm{N}$ ratios of the soils ranged narrowly between 9 and 9.5 ,indicating proportional increase in $\mathrm{C}$ and $\mathrm{N}$ in the fertilizer treatments. Addition of fertilizer manure resulted in a decline in soil $\mathrm{C}: \mathrm{N}$ ratios compared to the control but the differences were insignificant. The $\mathrm{pH}$ of soil was significantly influenced by the application of different fertilizer treatments instead of no remarkable differences between the treatments. The highest soil $\mathrm{pH}$ was observed with the application of $\mathrm{N}$ followed by other treatments.

\section{Conclusion}

The results showed that long term fertilization in paddy soil would result to variable properties of soil. Long-term application of fertilizer enhanced the essential properties in soils which may be favorable to sustain soil productivity and soil health. In case of long term fertilization, additional application of $\mathrm{N}, \mathrm{P}$ and $\mathrm{K}$ will be suggested. These three elements ensure essential amount of total $\mathrm{N}$ and organic carbon on soil.

\section{Conflict of interest statement}

All the authors do not have any possible conflicts of interest.

\section{Acknowledgements}

This research work was fully supported by revenue budget of Bangladesh Institute of Nuclear Agriculture (BINA), Mymensingh, Ministry of Agriculture, Bangladesh. The author expressed his deepest gratitude and appreciation to the scientists of soil science division of BINA for their inspiration and kind supports. The author also expressed his heartiest gratitude to all co-authors for their important technical as well as practical assistance in data collection, analysis and reporting regarding this research work.

\section{Significance statement}

Long term application of fertilizer increases the sustainability of essential nutrients in soil which provide favorable condition for crop production. Even after long term fertilization, additional N, P, K should be applied to enhance the more required nutrients.

\section{References}

[1] Bajpai R.L. and Prasad M. (1998). Factor productivity trends in a rice-wheat cropping system under long-term use of chemical fertilizers. Experimental Agriculture (India). 34(1): 1-18. https://doi.org/10.1017/S0014479798001070.

[2] Gong, W., Yan, X.Y., Wang, J.Y., Hu, T.X., and Gong, Y.B. (2009). Long-term manuring and fertilization effects on soil organic carbon pools under a wheat-maize cropping system in North China Plain. Plant Soil 314, 67-76 https://doi.org/10.1007/s11104-008-9705-2.

[3] Huang S., Zhang W., Yu X., and Huang Q. (2010). Effects of long-term fertilization on corn productivity and its sustainability in an Ultisol of southern China. Agriculture, Ecosystems \& Environment 138: 44-50. https://doi.org/10.1016/j.agee.2010.03.015.

[4] IPCC, (2001). Climate Change 2001: The Scientific Basis. Cambridge University Press, New York, USA.

[5] Jenkinson D S, Adams D E, and Wild A, (1991). Model estimates of CO2 emissions from soil in response to global warming. Nature, 351: $304-$ 306. https://doi.org/10.1038/351304a0.

[6] Molkonen, E. and Kukkola, M. (1991). Effect of long-term fertilization on the biomass production and nutrient status of scots pine stands. Fertilizers Research. 27(1): 113-127. https://doi.org/10.1007/BF01048614.

[7] Ramulu, S.U. (1990). Long-term effects in soil chemical properties due to continuous application of inorganic fertilizers and cattle manure to 122 crops. Trans. 14 Int. Cong. of Soil Sci. Kyoto, Japan, 12-18 August 1990. Vol. IV: 386-387.

[8] Su YZ., Wang F., Suo DR., Zhang ZH, and Du MW. (2006). Long-term effect of fertilizer and manure application on soil-carbon sequestration and soil fertility under the wheat-wheat-maize cropping system in northwest China. Nutrient Cycling in Agroecosystems 75: 285-295. https://doi.org/10.1007/s10705-006-9034-x.

[9] Suwara, I. and Gawronska-Kulesza, A. (1990). Effect of long-term fertilization and 3-field crop-rotation on some properties of soil. ZeszytyNaukowe-Akademii-Rolniczej-We-Wroclawiu. Rolnictwo (Poland). 196(53): 211-217.

[10] Valentini R, Matteucci G, Dolman A J et al. (2000). Respiration as the main determinant of carbon balance in European forests. Nature, 404: $862-$ 864. https://doi.org/10.1038/35009084.

[11] Yadav, R.L. (1998). Factor productivity trends in a rice-wheat cropping system under long-term use of chemical fertilizers. Experimental Agriculture (India). 34(1): 1-18. https://doi.org/10.1017/S0014479798001070. 